\title{
PREY OF NESTING RED-TAILED HAWKS AND GREAT HORNED OWLS ON LOSTWOOD NATIONAL WILDLIFE REFUGE, NORTH- WESTERN NORTH DAKOTA
}

ROBERT K. MURPHY, U.S. Fish and Wildlife Service-Des Lacs National Wildlife Refuge Complex, 8315 Hwy 8, Kenmare, ND 58746

Nesting Red-tailed Hawks recently nvaded and Great Horned Owls lave increased on Lostwood $\mathrm{Na}$ ional Wildlife Refuge (LNWR) in horthwestern North Dakota due to uccession from mixed-grass prairie 0 aspen parkland. ${ }^{6}$ Information on liets of these raptors could help reource managers assess the speies' needs and relationships with ther fauna, but such data are availble from few areas in the northern treat Plains. ${ }^{2,11}$ This paper summazes composition of prey of Redailed Hawks and Great Horned Owls bserved at nests on LNWR during a png-term study of raptor nesting cology. ${ }^{6}$

tudy Area and Methods LNWR is $08 \mathrm{~km}^{2}$ of rolling to hilly, semi-arid rassland interspersed with numerus temporary to permanent wetland asins and an average of about 12 lumps of Quaking (or Trembling) spen trees per $2.6-\mathrm{km}^{2}$ section. hysiography, geology, soils, habitat omposition, climate, and history of he area have been described. ${ }^{6}$

I observed fresh (still edible) prey ems during climbs to assess reprouctive success at Great Horned wl nests during early May and at
Red-tailed Hawk nests during late June, 1983-90. Prey were identified and left in nests. Data were pooled from all years for both raptor species and were summarized by relative (percentage) frequency.

Results and Discussion Forty-nine fresh prey were observed during about 200 climbs to Red-tailed Hawk nests and 53 fresh prey were observed during 78 climbs to Great Horned Owl nests. Although small prey were more likely to be overlooked than large prey by my methods, I assume effect of the bias was low. Birds were the most important prey of Red-tailed Hawks and especially of Great Horned Owls on LNWR (Table 1). Mammals generally comprise most Red-tailed Hawk prey during summer in other parts of the northern Great Plains ${ }^{2,1}$ and elsewhere. ${ }^{4}$ Nesting Great Horned Owls also tend to rely on mammals, ${ }^{4}$ although birds apparently dominate diets of Great Horned Owls in south central North Dakota. ${ }^{2}$ Rabbits and hares, important prey of Great Horned Owls in other north-central states and in adjacent provinces, ${ }^{1,3,10}$ probably were not preyed on more often on LNWR because they were scarce in the area. ${ }^{5}$ 


\begin{tabular}{|c|c|c|c|c|}
\hline \multirow[b]{2}{*}{ Prey ${ }^{\mathbf{a}}$} & \multicolumn{2}{|c|}{ Red-tailed Hawk } & \multicolumn{2}{|c|}{ Great Horned Owl } \\
\hline & number & $\%$ frequency & number & $\%$ frequency \\
\hline \multicolumn{5}{|l|}{ Mammals } \\
\hline Richardson's \& Thirteen-lined ground squirrels & 10 & 20.4 & 0 & - \\
\hline Meadow Vole and jumping mouse sp. & 4 & 8.2 & 6 & 11.3 \\
\hline White-tailed Jackrabbit (juvenile) & 1 & 2.0 & 5 & 9.4 \\
\hline Least Weasel & 1 & 2.0 & 0 & - \\
\hline Total mammals & 16 & 32.7 & 11 & 20.8 \\
\hline \multicolumn{5}{|l|}{ Birds } \\
\hline Homed or Eared grebe & 0 & - & 3 & 5.7 \\
\hline American Coot & $2^{b}$ & 4.1 & 12 & 22.6 \\
\hline Sora and Virginia rails & 0 & - & 2 & 3.8 \\
\hline Duck $^{\mathrm{c}}$ & $18^{d}$ & 36.7 & 14 & 26.4 \\
\hline Sharp-tailed Grouse & $5^{\theta}$ & 10.2 & 5 & 9.4 \\
\hline Blackbird & 1 & 2.0 & 6 & 11.3 \\
\hline Unknown passerines (juveniles) & 5 & 10.2 & 0 & - \\
\hline Total birds & 31 & 63.3 & 42 & 79.2 \\
\hline \multicolumn{5}{|l|}{ Other prey } \\
\hline Smooth Green Snake & 1 & 2.0 & 0 & - \\
\hline Band-winged Grasshopper (Oedipodinae) & 1 & 2.0 & 0 & - \\
\hline Total & 49 & 100.0 & 53 & 100.0 \\
\hline \multicolumn{5}{|c|}{$\begin{array}{l}\text { a Prey were adult size unless otherwise indicated. } \\
\text { b Both coot prey were juveniles. } \\
\text { c Adult duck prey included Mallard, Northem Pintail, Blue-winged Teal, Northem Shoveler, Gadwall, American } \\
\text { Wigeon, and Lesser Scaup. } \\
\text { d Duck prey of Red-tailed Hawk included nine juveniles. } \\
\text { o Grouse prey of Red-tailed Hawk included three juveniles. } \\
\text { ' Blackbird prey of Red-tailed Hawk was Red-winged Blackbird. Blackbird prey of Great Horned Owl included } \\
\text { Yellow-headed Blackbird, Common Grackle, and Brown-headed Cowbird. }\end{array}$} \\
\hline
\end{tabular}

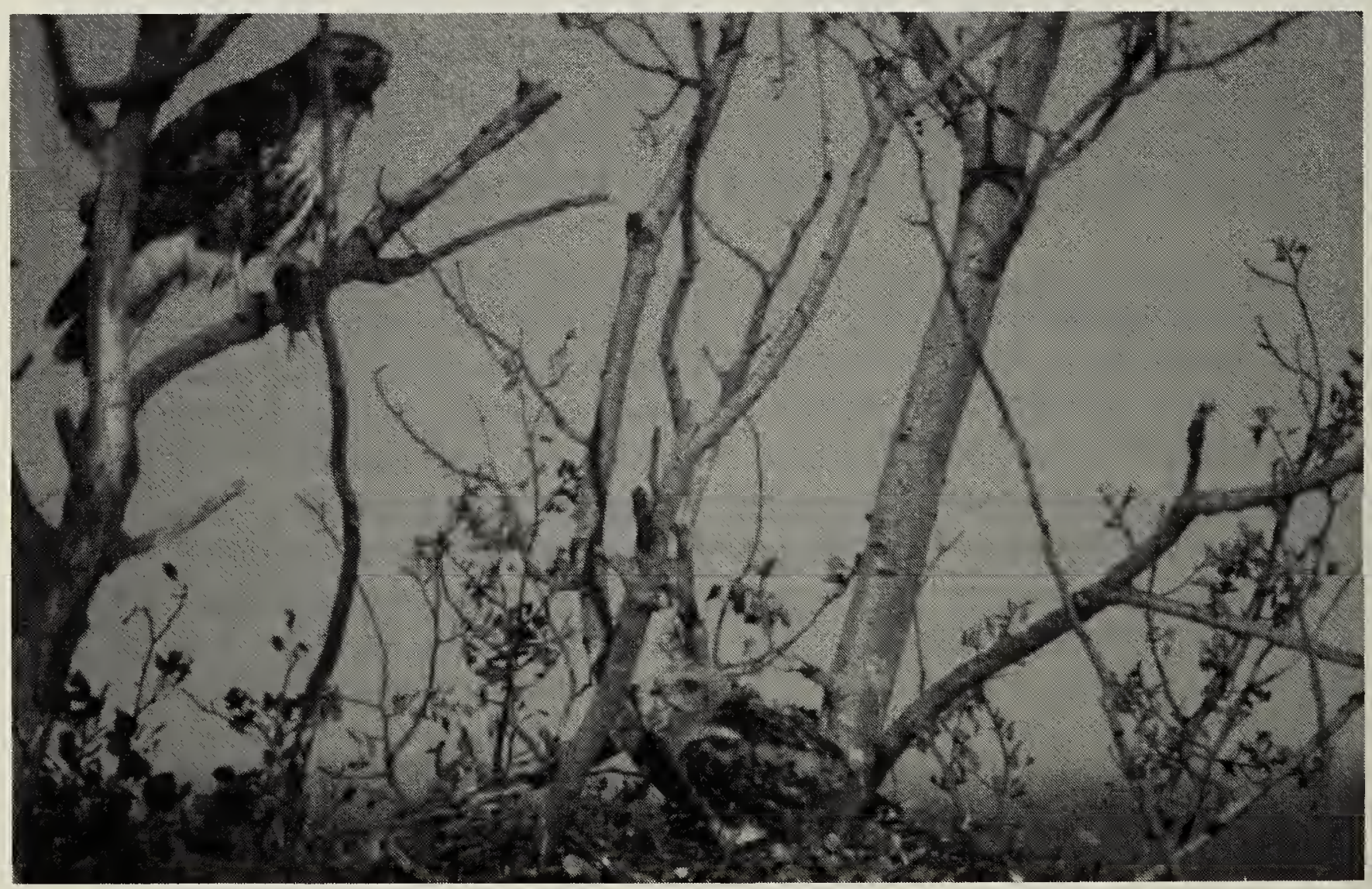

Red-tailed hawk delivers meadow vole prey to its nestling on Lostwood National Wildlife Refuge, North Dakota

Robert K. Murphy 
About $43 \%$ of Red-tailed Hawk prey and $64 \%$ of Great Horned Owl prey were species directly associated with wetlands, such as American Coot, ducks, and Yellow-headed Blackbird, even though wetland habitat comprised only $20 \%$ of LNWR. Thus, use of wetland-dependent prey by both raptor species was greater than expected based on the availability of wetland habitat. The most important prey groups were birds from wetlands (Table 1), especially American Coot for Great Horned Owls and ducks for both species of raptors. One-half of duck prey of Red-tailed Hawks were ducklings, all but one of these less than a week old. Female ducks made up $79 \%$ of 14 adult duck prey of Great Horned Owls. I did not estimate prey composition by biomass (weight) but believe wetland- dependent birds contributed most prey biomass used by nesting Great Horned Owls based on frequency of grebes, American Coot, and ducks observed. Wetlanddependent birds dominated biomass of the owl's diet on a nearby area of mixed land use. ${ }^{8}$

Another important prey group used by Red-tailed Hawks was ground squirrels (Table 1). Most $(80 \%)$ were Richardson's Ground Squirrels that may have been captured on heavily grazed prairie adjacent to LNWR. Franklin's Ground Squirrels occurred on LNWR ${ }^{5}$ but were not observed as prey of either Red-tailed Hawks or Great Horned Owls.

Overlap in the diets of co-existing Red-tailed Hawks and Great Horned Owls has been studied previously in North America, based on prey remains or pellets at nests. ${ }^{2,4}$ However, a six-week disparity in nesting chronology between the two species on LNWR $^{7}$ rendered such comparisons weak. In summer nearly one-half of mammal and bird prey of Red-tailed Hawks were juveniles, but about the only juvenile vertebrate prey available in spring when Great Horned Owl diets were recorded were small (less than one-eighth grown) jackrabbits; the owls used this prey (Table 1). Great Horned Owls would have preyed on different age classes and perhaps species of prey during summer compared to spring, as they did on nearby areas of mixed land use. ${ }^{8}$

My cursory survey suggests birds, especially those from wetlands, are the most important prey of nesting Red-tailed Hawks and Great Horned Owls on LNWR during each raptor's respective nestling period. Great Horned Owls seemed particularly tied to wetland-dependent prey, which supports observations of a strong affinity for wetland habitats by the owl on LNWR. ${ }^{6}$ Relative composition of Red-tailed Hawk and Great Horned Owl diets on LNWR were similar to those noted in southcentral North Dakota ${ }^{2}$ except that Red-tailed Hawks on LNWR relied more on bird prey, and ducks were more important to both the hawk and owl on LNWR.

Acknowledgments John Ensign and Karen Smith lent expert help in the field, and R.L. Eng and Alan B. Sargeant commented on a manuscript draft.

1. ERRINGTON, P.L., F. HAMERSTROM and F.N. HAMERSTROM, Jr. 1940. The Great Horned Owl and its prey in north-central United States. lowa Agric. Exp. Stn. Res. Bull. 227:758-850.

2. GILMER, D.S., P.M. KONRAD and R.E. STEWART. 1983. Nesting ecology of Red-tailed Hawks and Great Horned Owls in central North Dakota and their interactions with other large raptors. Prairie Nat. 15:133-143. 
3. HOUSTON, C.S. 1987. Nearly synchronous cycles of the Great Horned Owl and Snowshoe Hare in Saskatchewan. U.S. For. Serv. Gen. Tech. Rep. RM-142:56-58.

4. MARTI, C.D. and M.N. KOCHERT. 1995. Are red-tailed hawks and great horned owls diurnal-nocturnal dietary counterparts? Wilson Bull. 107:615628.

5. MURPHY, R.K. 1990. Vertebrate fauna of Lostwood National Wildlife Refuge: an annotated checklist. U.S. Fish Wildl. Serv. refuge leaflet publ.

6. 1993. History, nesting biology, and predation ecology of raptors in the Missouri Coteau of northwestern North Dakota. Ph.D. thesis, Montana State Univ., Bozeman. 212 pp.

7. 1996. Raptor nesting chronology in northwestern North Dakota. Prairie Nat. 28: In Press.
8. 1997. Importance of prairie wetlands and avian prey to breeding Great Horned Owls (Bubo virginianus) in northwestern North Dakota. In Proceedings of a symposium, Biology and Conservation of Owls of the Northern Hemisphere. U.S. For. Serv. Gen. Tech. Rep.: In Press.

9. PALMER, R.S., ed. 1988. Handbook of North American birds, Vol. 5. Yale Univ. Press, New Haven, CT. 465 pp.

10. PETERSEN, L. 1979. Ecology of Great Horned Owls and Red-tailed Hawks in southeastern Wisconsin. Wis. Dep. Nat. Resour. Tech. Bull. 111:1-63.

11. SCHMUTZ, J.K., S.M. SCHMUTZ and D.A. BOAG. 1980. Coexistence of three species of hawks (Buteo spp.) in the prairie-parkland ecotone. Can. J. Zool. 58:1075-1079.

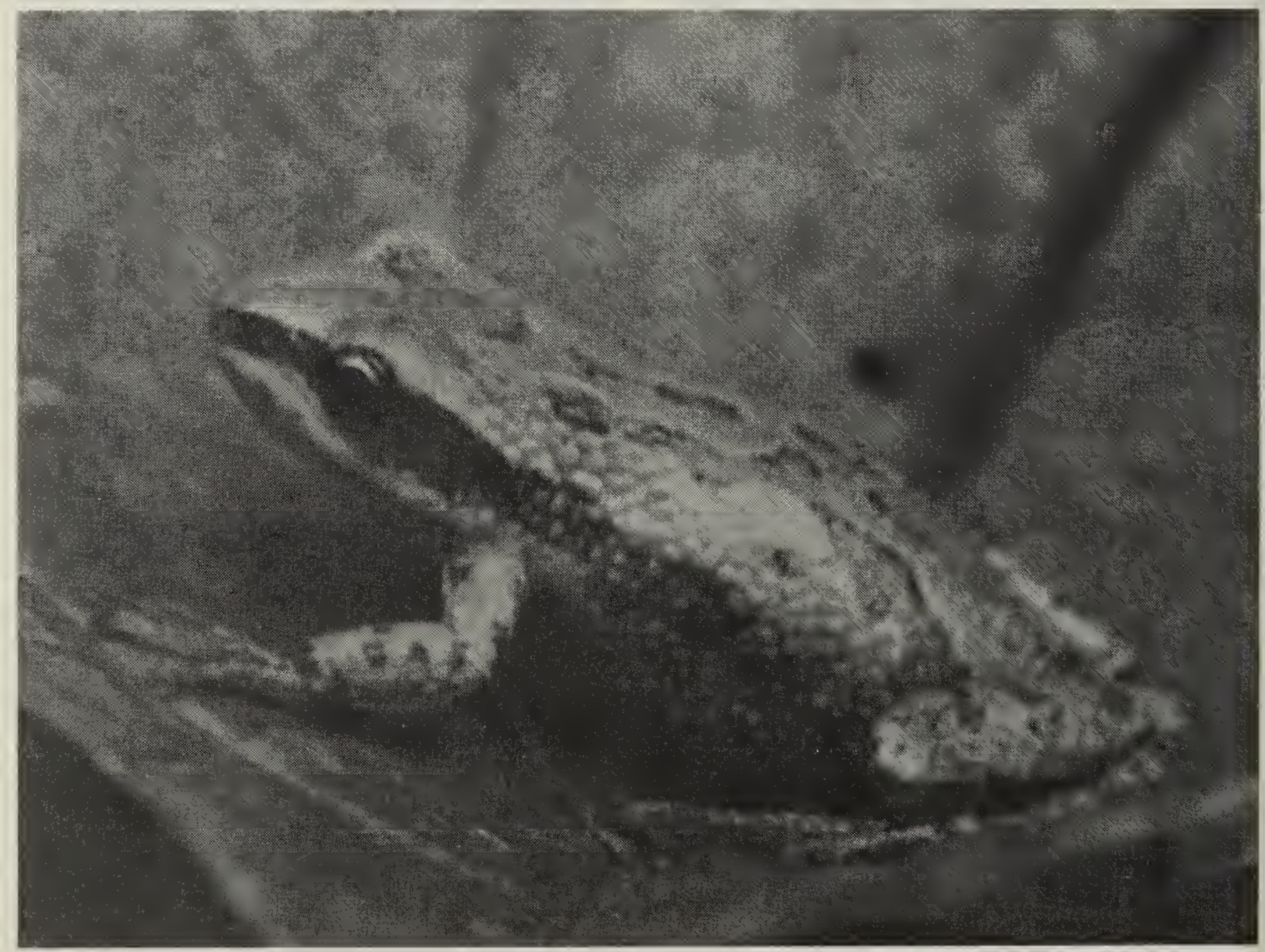

